\title{
OBITUARY
}

\section{CHARLES SCOTT SHERRINGTON}

By the death of Sir Charles Scott Sherrington, O.M., G.B.E., F.R.S., at the ripe old age of 94, the world has lost one of its greatest scientists and one who contributed to ophthalmology, although incidentally, yet on a grand scale. Sherrington's scientific life was devoted mainly to the study of the central nervous system, the complexities of which were elucidated for the first time through his recognition that the simple spinal reflex was a unit which could be adequately studied by the experimental method. Advancing in this way from the simple to the complex and applying an experimental ingenuity which was unique with an industry and fertility of thought which were astonishing throughout a laboratory life of over fifty years, he synthesized into an integrated philosophy a subject which he had found in the early eighties of the nineteenth century a chaos of vague generalities. From the ophthalmological point of view, his crucial experiments on the reciprocal innervation of the ocular muscles and the perceptual processes involved in binocular vision will always remain fundamental landmarks in our knowledge. Nor were his life and activity confined to the laboratory: a philosopher and a poet of no mean order, an energetic man of affairs, an eminent public speaker, unspoiled by all the honours that Great Britain and the international world of science were proud to bestow upon him, he remained to the end one of the most endearing and modest of men.

\section{LOUIS BRAILLE CENTENARY}

THE Royal Society of Arts held a special meeting on March 5, 1952, to commemorate the centenary of Louis Braille, who died on January 6, 1852. His Excellency the French Ambassador, M. René Massigli, G.C.V.O., K.B.E., was in the Chair. An appreciation of Louis Braille and his work for the blind was read by Vernon Barlow. 